\title{
Intelligent Pedagogical Model with Kinesthetic-Static Immersion based on the Neuro-Linguistic Programming Approach (NLP)
}

\author{
Simón Choquehuayta Palomino ${ }^{1}$, José Herrera Quispe ${ }^{2}$, Luis Alfaro ${ }^{3}$, Blas Choquehuayta Llamoca ${ }^{4}$ \\ Universidad Nacional de San Agustin de Arequipa, Peru
}

\begin{abstract}
In this paper, the authors propose a teaching/learning pedagogical model, based on an approach that uses neurolinguistic programming, educational data mining and haptic interaction. It also uses the theory of learning styles, which are identified with data mining techniques, clustering and the Farthest First algorithm, as well as a test of Neurolinguistic Programming. Depending on the results obtained, the teaching/learning strategies are defined, and the activities of an educational coaching are suggested, with the purpose of boosting the students' attention in the classroom, stimulating their communicative and psychomotor skills. The proposal was evaluated with a sample of students of regular basic education, to whom an instrument was applied before and after carrying out the tests of applying the plan of the teaching/learning activities. For this purpose, a multifunctional learning kit was constructed, which is a didactic and playful resource, applicable to the student's psychomotor area. The kit contains an application and a hardware device called "Tusuna-pad 1.0", which was implemented in the Unity games engine and was programmed using the $\mathrm{C} \#$ language. The pedagogical model was validated with the participation of students of Regular Basic Education, considering pedagogical and computational aspects, results that were validated and duly analyzed. Finally, conclusions and recommendations for future work were established.
\end{abstract}

Keywords-Haptic interaction; viral immersion; learning styles; neuro-linguistic programming; educational data mining

\section{INTRODUCTION}

Every year, during the learning process, educators encounter students who belong to generations of the digital age, most of whom are familiar with computers and technological devices from society, such as computational supports or devices. For example, for Gramingna [1], games with virtual environments have the following characteristics: a) they allow interaction between the user and the device; b) when playing, users are involved in a simple way; c) they foster interest, making learning posible; d) they allow the trial to be associated with the reward, and e) both hemispheres are activated, promoting new ways of thinking.

Related to the pedagogical aspect, Sanchez [2] states that students learn in many ways: seeing and listening, reflecting and acting, reasoning logically and intuitively, memorizing and visualizing, constructing analogies and playing. Indeed, leisure activities [3] have been the driving force and one of the most effective modes of learning since the appearance of man. Through them it is possible to learn different things, some pleasant, others conflictive, such as experimenting, making mistakes [4] and putting oneself in the place of others, above all by doing and playing [5], so that the motivated student can adapt to the educational context and the learning is flexible enough. These are conditions that the student needs in order to be open-minded and to explore the knowledge of a certain thematic line through a computing environment.

\section{Motivation}

In the Arequipa region, few research studies attempt to solve educational problems with data mining; and if they do exist, they are focused on higher education [6][7], and there are no studies for EBR, therefore the use of data mining techniques is proposed to detect the predominant learning style of the student [8][9], according to the NLP approach. Depending on the predominant style, teaching strategies and coaching activities should be applied in a playful interactive environment with haptic-kinesthetic immersion based on NLP, understanding that psychomotor communicative skills have their implications in body expression Choquehuayta [10].

Failure to contribute to the strengthening of psychomotor skills in time could have an impact on learning difficulties. In the case of mathematics, if one does not work on body laterality in the school stage between 2 and 5 years of age, the child will not be able to start adding or subtracting several quantities from right to left [11]. It has been proven that the psychomotricity of kinaesthetics increases the reality of the subject and brings some action to the data and meanings [12]; and this helps us notably with the comprehensive assimilation of the information of any content. It should be noted that in studies presented at the 2005 Harvard Conference [13], music video games can improve concentration skills as well as psychomotor communication skills; for example, a recent exploratory study of 1500 high school students showed significant increases in reading fluency and math fluency, as well as significantly improved attention [14]. Based on the rationale, is EAIHK-NLP likely to enable EBR students to strengthen psychomotor communication skills, thereby enhancing attention?

\section{STATE OF THE ART REVIEW}

Juan Olague and Socrates Torres [15] developed the project "Application of data mining techniques and learning content management systems for the development of a computer learning system of computer programming" [16], whose main objective was the description of learning styles in the students of the career of Computer Science and of course 
they elaborate a software that would facilitate to learn the subject of computer programming better, once its style has been detected. Gutiérrez and Solórzano [17] cite a phrase from Confucius that says: "I hear and I forget; I see and I remember; I do and I understand"; they consider that this phrase manifests the effectiveness of learning based on experiential learning that is characterized by sustaining that "one learns by doing", and where it is considered that the student should actively participate in his or her own learning process in such a way that his or her capacity to learn to learn is strengthened, understanding one's own way of learning and the processes that are required for it.

The use of data mining in education is encouraged to describe and predict learning styles with the work "identification of dominant learning styles in computer students" [18], and in Durán et.al. [19], present the work "Data Mining to describe Learning styles". In this work they used the instrument created by [20], which consists of 44 questions with two answer options each, in which the student must necessarily choose one of them, and then perform an analysis of the data in Weka using the Clustering technique and the FarthestFirst algorithm, and for the display of data, they used the Torta graph. The second work of the previous paragraph used the instrument of the Felder-Silverman model [21]. This only considers 4 dimensions and not 5 as the first one. Cumbirayco [22], in her work entitled "Neurolinguistic programming in students' strategic learning" at the Universidad César Vallejo, concludes that the applicability of NLP makes great sense, since it is an effective and simple tool that allows a significant change in the student's academic performance.

\section{OBJECT OF THE RESEARCH}

To propose a learning pedagogy based on the learning approach of NLP, with the purpose of contributing to the improvement of psychomotor communicative skills, consequently enhancing the attention of EBR students.

\section{TOPICS INVOLVED IN THE RESEARCH}

\section{A. Educational Data Mining (EDM)}

EDM can transform the raw data collected by learning systems into useful information that can be used to make informed decisions and answer research questions [23]. EDM is an emerging discipline at the intersection of data mining and pedagogy. While pedagogy provides the intrinsic knowledge of the learning process, data mining provides the techniques of information analysis and modeling. In Fig. 1, we present the elements that make up its structure.

\section{B. Neuro-Linguistic Programming}

The NLP, through analogy with the computer, uses the universal patterns of communication and perception that we have to recognize and intervene in diverse processes: learning, therapy, other conflicts [25]. Neuro-linguistic programming offers us invaluable tools to give students a personalized, efficient education, seeing them as individuals in order to be able to provide them with the required information in an effective manner.

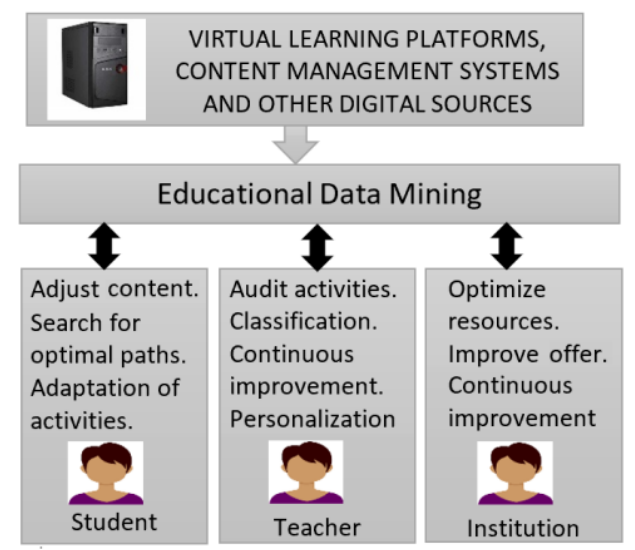

Fig. 1. Elements in Educational Data Mining Source: Ballesteros J, Sánchez D., \& García R. [24].

\section{Haptic Interaction}

Haptic interaction considers both the tactile (touching) and kinesthetic (movement) [26]. By means of kinesthesia the muscular movement, weight and position of the corporal parts are perceived. (C. Colwell, H. Petrie, A. Hardwick and S. Furner, 1998) write about the close link between perception and action in haptic functioning. This means that in order to perceive haptics, the user must move actively in computer interaction [27].

\section{Play and its Importance in Education}

Play is considered as one of the most enjoyable and significant activities of the human being, which can also be used as a learning strategy for the acquisition of knowledge, both in the classroom and virtual environments [28]. For example, Rocha [29] in his work concluded that the application of play in the educational field considers motivations, interests, and the evolutionary characteristics of learners. Torres [30] also points to play as a learning strategy that leads students to the world of knowledge. Chacón [31] forcefully reveals that play has an educational objective that includes moments of pre-reflective action and of abstractlogical symbolization or appropriation of what has been lived in order to achieve the objectives of curricular teachings.

1) Educational video games: These are interactive multimedia materials through which one or several topics can be learned. An important characteristic is that the knowledge is acquired in an implicit way, that is to say, the players do not realize that while playing they are acquiring a series of concrete skills, but that they are acquiring them in the natural course of the videogame [32].

\section{METhodologiCAL DESIGN AND ELEMENTS APPLIED IN THE PROPOSAL}

The method used for the development of this work is a quasi-experimental descriptive study [33], with a tendency to action research [34] in information systems, which has become one of the main methods of qualitative research in the field of information systems and software engineering [35]. 


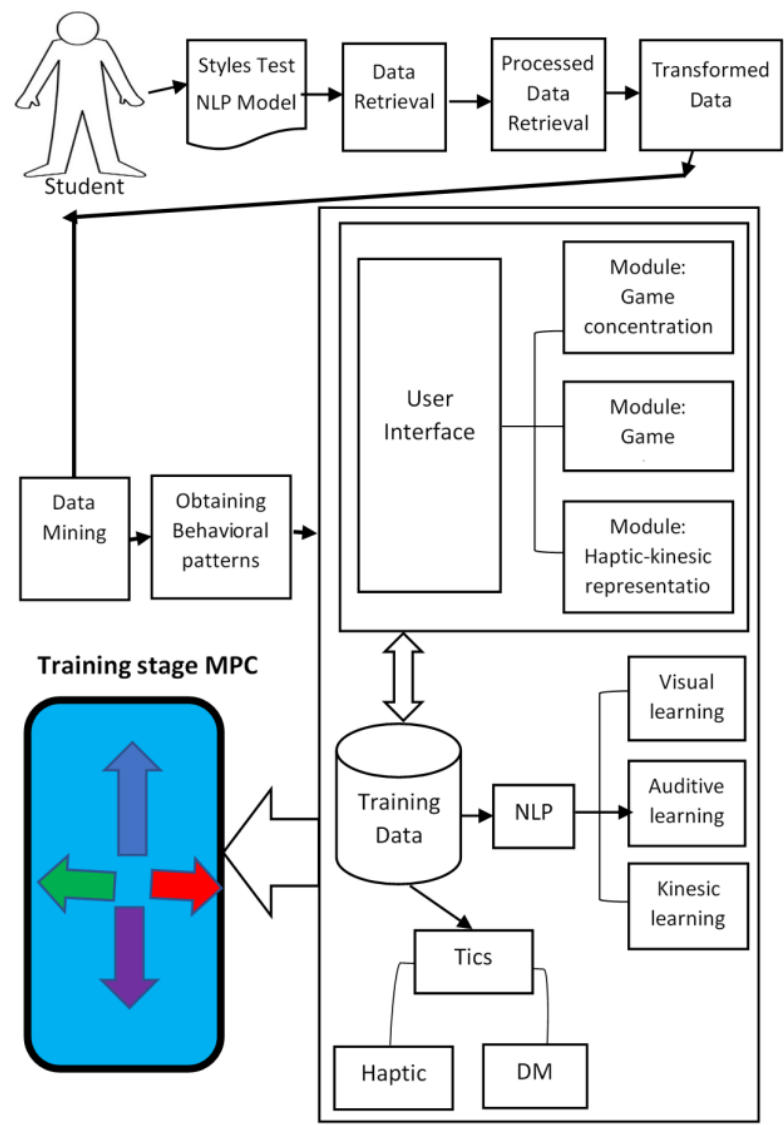

Fig. 2. General Outline of the Proposal Source: Taken from [43].

The DM process was applied for the discovery of knowledge and, based on the results, the computational pedagogical material (MPC) was implemented. Fig. 2 presents the general scheme of the methodology applied. According to Matas and Dalmau [36] it is suggested that the proposals should be schematized.

\section{PROCEDURAL DESIGN OF THE PROPOSAL}

From the many processes as shown in Fig. 2, the student is considered first for the DM process and data collection. Applying the information collection instrument, the NLP learning styles test [37], which is made up of 40 questions, each with three alternative solutions, which represent a specific style, the student can only mark one answer. Table X shows a part of the 40 questions of the questionnaire modified in form and content for students of the 5th cycle (5th and 6th grade) of EBR at IE 40134 primary education. For the validation of the proposal we worked with the card shown in Table I, the same that was used for the pre-test and post-test of the experiment. This instrument was applied to 90\% (92 students) of the population of 108 students.

With the information provided by the test per student, a database was generated to submit it to the KDD process (Knowledge Discovery in Database) [38]. Of course, the data mining technique "cluster analysis" was applied, based on the common characteristics of a certain number of groups; this type of analysis is used to classify individuals to identify homogeneous subgroups within the sample of respondents.
From the process, it was found that the student group under study has a high predominance of the kinesthetic-saptic learning system. As a result, the majority of students interact in virtual environments that are generally related to leisure. The multifunctional kit called "Tusuna-pad 1.0" was implemented, which is an application and device with protocol to the PC. This MPC was used in 6 learning sessions of educational coaching (1 per month); with the intention of strengthening psychomotor communication skills, especially regarding attention. To this effect, the heading of Table I of the development of the instructional plan was applied.

TABLE. I. HEADING APPLIED FOR VALIDATION

\begin{tabular}{|c|c|c|c|}
\hline \multicolumn{2}{|l|}{ Criteria / Points } & Rating levels / Punctuation & Value \\
\hline \multirow{4}{*}{$\begin{array}{l}\text { Jump with both } \\
\text { feet on the mat, } \\
\text { located on the } \\
\text { floor. }\end{array}$} & 1 & $\begin{array}{l}\text { It is not driven and does not put both feet at the } \\
\text { same time in case there is a left-right arrow }\end{array}$ & \\
\hline & 2 & $\begin{array}{l}\text { It flexes the trunk and drives with both legs. It does } \\
\text { not fall on the mat. }\end{array}$ & \\
\hline & 3 & $\begin{array}{l}\text { It drives and stands on the left-right arrows with } \\
\text { both legs, while coordinating the simultaneous } \\
\text { extension of arms. }\end{array}$ & \\
\hline & 4 & $\begin{array}{l}\text { It is energized by stepping on the circles with } \\
\text { arrows as appropriate }\end{array}$ & \\
\hline \multirow{4}{*}{$\begin{array}{l}\text { Perform the } \\
\text { jump and move } \\
\text { the trunk from } \\
\text { the body to the } \\
\text { compass. }\end{array}$} & 1 & Make $90^{\circ}$ movement & \\
\hline & 2 & Make trunk movement up-down & \\
\hline & 3 & Make foot movement with great agility & \\
\hline & 4 & $\begin{array}{l}\text { Make movement to put the feet and legs in } 180^{\circ} \\
\text { with great agility }\end{array}$ & \\
\hline \multirow{4}{*}{$\begin{array}{l}\text { Retains body } \\
\text { coordination } \\
\text { and balance on } \\
\text { the mat }\end{array}$} & 1 & $\begin{array}{l}\text { Coordinates a fluid movement from the legs and } \\
\text { trunk to the arms }\end{array}$ & \\
\hline & 2 & $\begin{array}{l}\text { There is flexion and extension of the knee and leg } \\
\text { when stepping on the circles of the mat }\end{array}$ & \\
\hline & 3 & $\begin{array}{l}\text { It balances on your leg without having much } \\
\text { inclination to the ends of the mat. }\end{array}$ & \\
\hline & 4 & $\begin{array}{l}\text { The sequence of movement of the feet and legs is } \\
\text { rhythmic }\end{array}$ & \\
\hline \multirow{4}{*}{ Participation } & 1 & Only one or two people actively participate & \\
\hline & 2 & At least half of the students actively participate & \\
\hline & 3 & At least $3 / 4$ of the students actively participate & \\
\hline & 4 & All students participate enthusiastically & \\
\hline \multirow{4}{*}{$\begin{array}{l}\text { Interaction } \\
\text { quality }\end{array}$} & 1 & $\begin{array}{l}\text { Very little interaction: very short conversation; } \\
\text { some students are distracted or disinterested }\end{array}$ & \\
\hline & 2 & $\begin{array}{l}\text { It favors coexistence and contributes to the } \\
\text { resolution of conflicts in a peaceful way }\end{array}$ & \\
\hline & 3 & $\begin{array}{l}\text { Students show being versed in the interaction; lead } \\
\text { lively discussions centered on the game }\end{array}$ & \\
\hline & 4 & $\begin{array}{l}\text { Demonstrate attitudes of tolerance and respect for } \\
\text { the possibilities and limitations of others in game }\end{array}$ & \\
\hline \multicolumn{3}{|l|}{ Total } & \\
\hline
\end{tabular}

VIII. ORGANIZATION OF THE LOGICAL STRUCTURE Pertaining to THE MultifunCtional LEARNing Kit

Prototype contextualized to our region with peculiarities and terms characteristic of the Andean culture. It is aimed at 
children from 8 to 12 years old and is used in innovation and physical education classrooms (psychomotor area).

\section{A. Navigability Scheme of the Multi-Functional Kit}

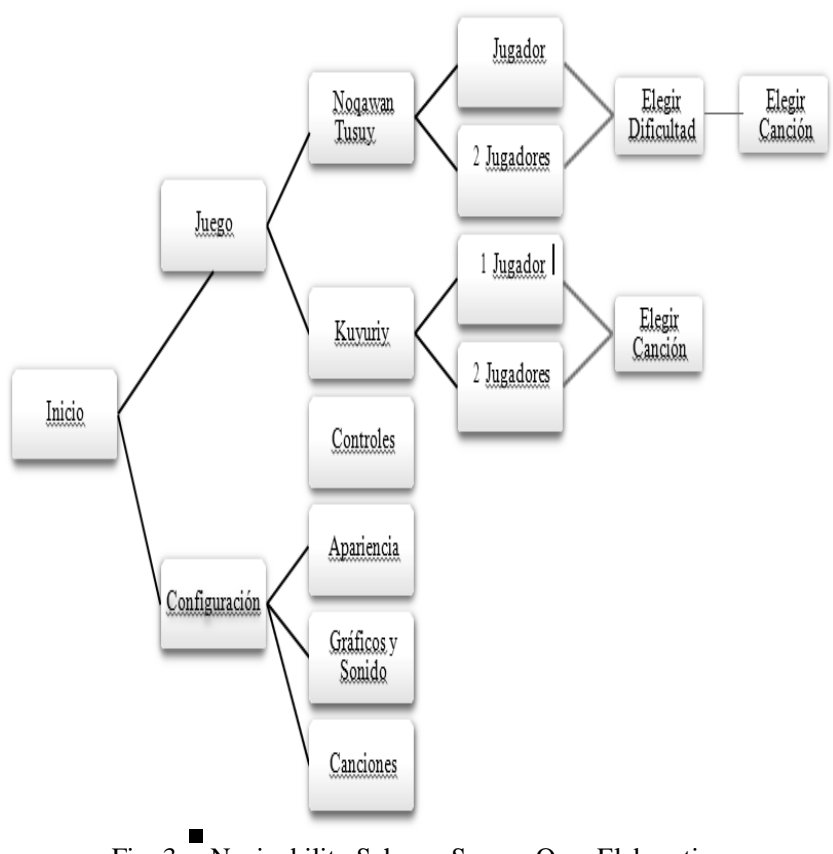

Fig. 3. Navigability Scheme Source:Own Elaboration.

\section{B. Diagrams}

In this section we present the user case diagram according to Fig. 4, and the administrator case diagram Fig. 5. Fig. 10 shows the hardware device corresponding to the kit.

\section{Interface}

It consists of two modules as shown in Fig. 6. The elements of the prototype were implemented in the Unity game engine and its $\mathrm{C \#}$ coding.

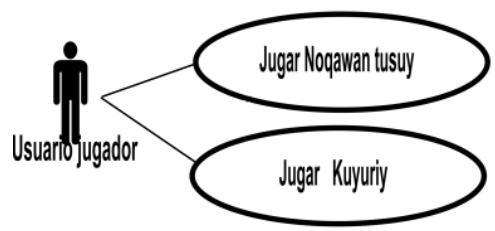

Fig. 4. Usage Case Diagram Source: Own Elaboration.

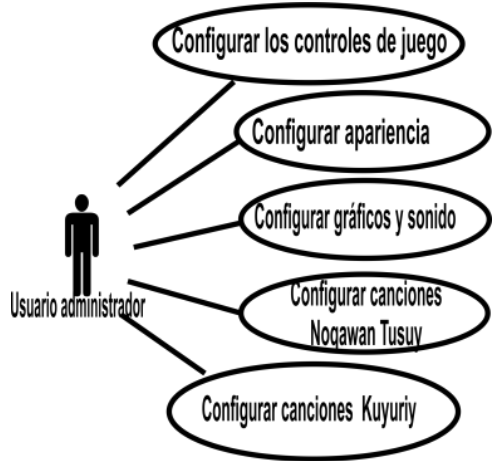

Fig. 5. Usage Case Diagram Source Own Elaboration.

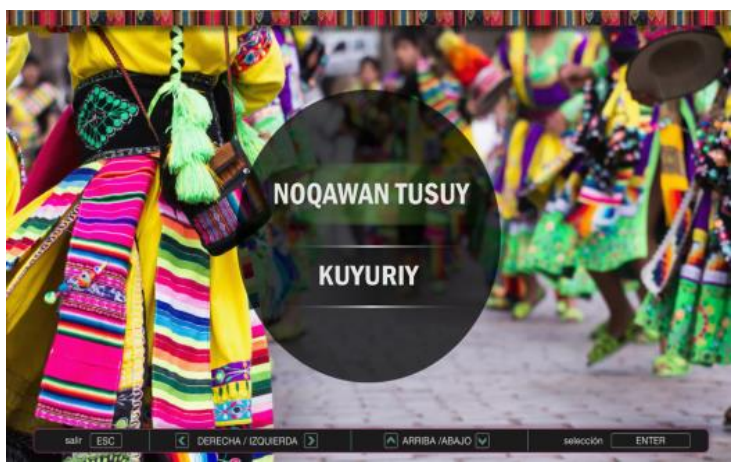

Fig. 6. Youruna-Pad Learning Kit Modules Source: Own elaboration.

Fig. 6 refers to the "Kuyurity" module that results from an innovation of the "Twister" game, which does not have an interface and a firm platform, which does not evaluate the levels of attention of the user player, nor does it have reports of the scores or statistics, elements that were implied in the proposed model. The screen of the "Kuyurity"game is observed in Fig. 7, and then the final game report with the respective ratings and statistics concerning the attitudinal aspect. In Fig. 8, Rapid Rhythm, the level of attention is divided into the qualifications based on Tables VIII and IX.

According to this table the logic of the application is described, with respect to the qualification that the user obtains, when the application is executed. The final percentage is obtained by means of a simple rule of three, where the total quantity of arrows, equivalent to $100 \%$, results from the sum of the perfect points plus the failed points.

The report of Fig. 8, achieved by the user, attention level and rhythm, is based on the percentages and data of Tables VIII and IX. For example percentage calculation: A final report of a player, at the end of the piece of music in the user's environment. You get the total number of arrows: $238+85=$ 323 , then apply a simple rule of three to obtain Percentage

323 $100 \%$

238 $\mathrm{X} \%$

$\mathrm{X}=73 \%$

According to the equation (1) and Table IX, $73 \%$ are in the last range, which is equivalent to a Divided Attention Level and Rapid Rhythm qualitatively qualifying as "Good".

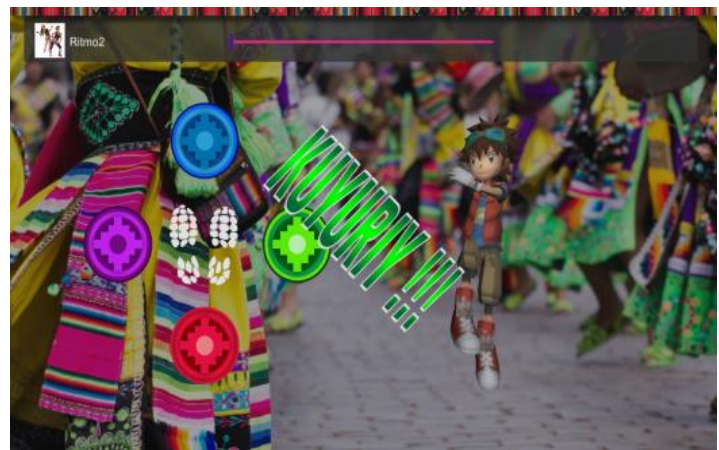

Fig. 7. "Kuyuriy" Module Source: Own Elaboration. 


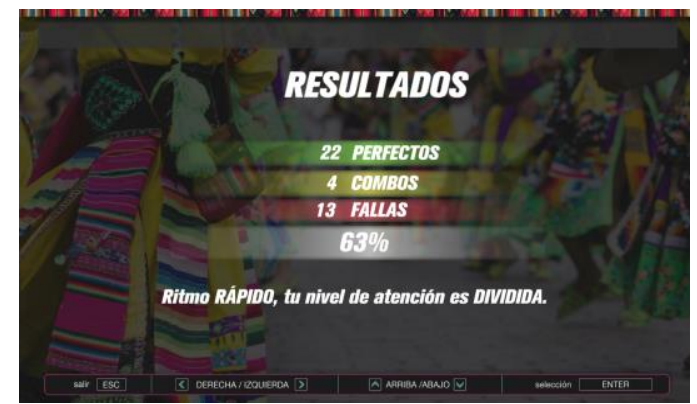

Fig. 8. Results Screen of the "Kuyuriy" Game Source: Own Elaboration.

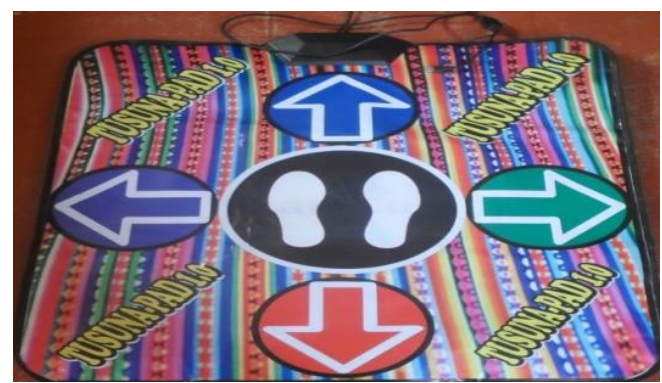

Fig. 9. Tusuna-Pad Hardware Device Source: Own Elaboration.

Fig. 9, shows a photo of the pad or mat, which connects to a Pc, which of course becomes a dance platform, an improved model of what was presented at TISE 2011 [10] called "Chaqui-pad". In order to work with this MPC, classroom session plans were planned, known as the Pedagogical Practice Proposal (PPP), material presented in Table VI, which allowed for the organization and planning of learning objects and activities, as well as for the evaluation of the student's psychomotor communication skills and abilities.

\section{REsUlts ANALYSIS}

\section{A. Processes for Detection of Learning Style based on the NLP Model} 401344

a) Selection stage: 108 students were selected from IE

b) Stage of data cleansing and elaboration: For this purpose, exploratory tasks were carried out analyzing each of the cards registered in a table, achieving the elimination of inconsistencies, through manual corrections, such as the existence of unmarked alternatives, definition of double marking and other typographical errors, including the elimination of cards such as damaged and blank tests, supposedly generated by some nonconformity to the test.

c) Data mining: Once the Excel file has been saved: (IE40134. XLSx) with the tabulated PNL test data, we found a record of 108 students and 44 fields (columns) to be analyzed quantitatively and qualitatively by means of the Weka tool. Fig. 10 reports stored data ready to be exported to CVS format (format that allows to separate fields separated by commas in Excel) to load it into a text editor; in this case, it was the Editplus application; it could also be loaded into Wordpad but this lacks other functions that the case requires. Fig. 11 presents the file in Editplus.

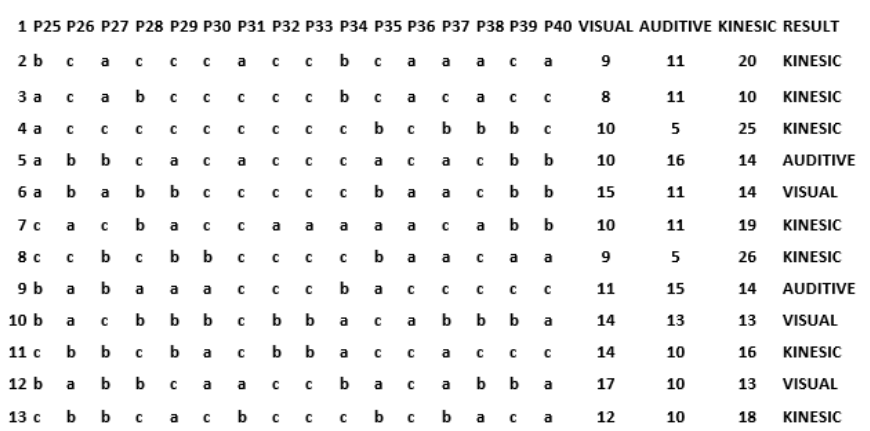

Fig. 10. Tabulated Test Data in Excel Source: Own Elaboration.

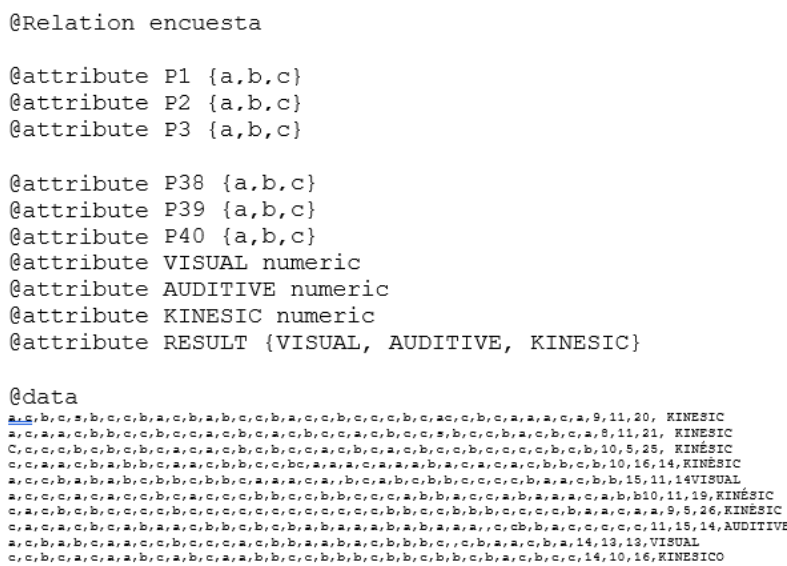

Fig. 11. File in CVS Format to Generate Arff. File Source: Own Elaboration.

\section{A. Results of the DM process}

The results were guided by the five questions posed by Han and Kamber [39]; Fig. 12 shows the data clustering, which is described as follows

- Which dataset was considered relevant to discovering the knowledge?

108 students in the 5 th cycle as a result of preprocessing.

- What kind of knowledge is to be discovered??

The type of knowledge to be discovered is the des criptive type. Specifically, cluster analysis was applied (Witten and Frank, 1999) to identify homogeneous subgroups within the surveyed student population. For this, the DM tool was used, and the Cluster option was selected. [40] In particular, the FarthestFirst algorithm was chosen because it is a problem of $\mathrm{k}$ centres where the maximum distance between a tuple and its centroid is intended to be minimum [41]. In order to detect the dominant learning styles, it was decided to keep the number of clusters (0.1) to be generated in two. As can be seen in the results, there is no need to expand this number given the high percentage of tuples included in the first cluster.

- What measures can be used to estimate patterns of interest?

From this knowledge it was decided to replace each of the attributes included in the two centroids of the clusters cast by Weka with the code of the learning style with which it is linked (Table IV), with which the centroids were expressed as. 


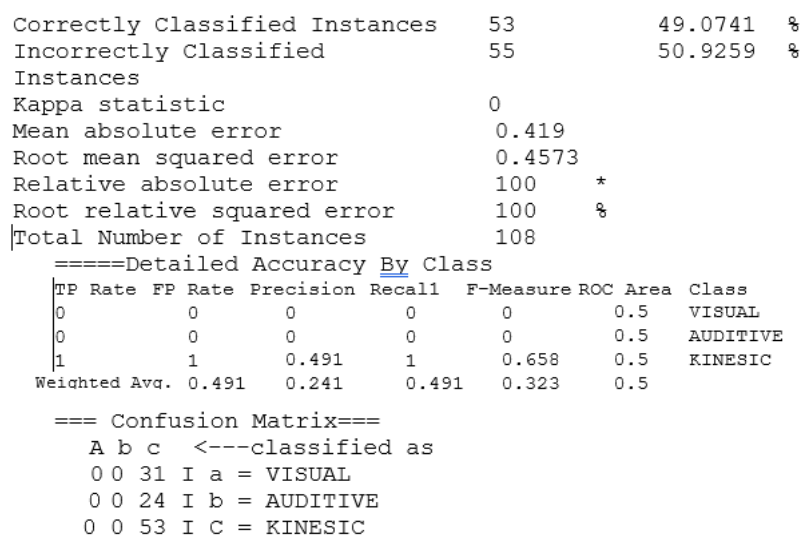

Fig. 12. Determiation of the Dominant Kinesthetic Style Sourde: Own Elaboration.

\section{Cluster Centroid 0:}

k, v, a, a, a, k, k, k, a, k, a, k, k, k, a, k, v, v, k, a, a, v, k, a, k, a, k, v, $\mathrm{k}, \mathrm{v}, \mathrm{v}, \mathrm{v}, \mathrm{k}, \mathrm{v}, \mathrm{a}, \mathrm{v}, \mathrm{a}, \mathrm{k}, \mathrm{k}, \mathrm{v}$

\section{Cluster Centroid 1:}

a, v, k, v, v, v, k, k, k, a, k, a, v, v, k, a, v, k, v, a, k, v, a, k, v, v, v, k, $\mathrm{a}, \mathrm{a}, \mathrm{a}, \mathrm{k}, \mathrm{v}, \mathrm{v}, \mathrm{v}, \mathrm{k}, \mathrm{k}, \mathrm{k}, \mathrm{v}, \mathrm{k}$

In order to determine the combination of learning styles, represented by each centroid, the number of occurrences of each style was counted. Result:

Cluster Centroid 0: V=11 A=12 K=17

This centroid represents the most dominant kinesthetic style of the group, followed by auditory and visual.

Cluster Centroid 1: $\mathrm{V}=16 \mathrm{~A}=9 \mathrm{~K}=15$

So this centroid represents Visual, kinesthetic and auditory style (see Table II).

- What background knowledge will be useful?

Based on the characteristics defined by Richard Blander, the correspondences between the learning styles and the possible answers to the forty questions of the NLP model test were determined. The information in Fig. 13 can easily be expressed as a rule-based hierarchy in order to represent the hierarchies of concepts obtained from our knowledge of the domain.

\section{- Visualization of discovered patterns}

Fig. 14 shows the patterns discovered in a bar graph, the resulting clusters as a function of the percentage of tuples included in each cluster. $52 \%$ of the population under study constituted the first cluster and $48 \%$ the second cluster.

TABLE. II. LEARNING STYLES AND THEIR CORRESPONDING REPLACED CODE

\begin{tabular}{|l|l|}
\hline Learning styles & Code \\
\hline Visual & $\mathrm{V} \rightarrow \mathrm{b}$ \\
\hline Auditive & $\mathrm{A} \rightarrow \mathrm{a}$ \\
\hline Kinesthetic & $\mathrm{K} \rightarrow \mathrm{c}$ \\
\hline
\end{tabular}

Source: Own source

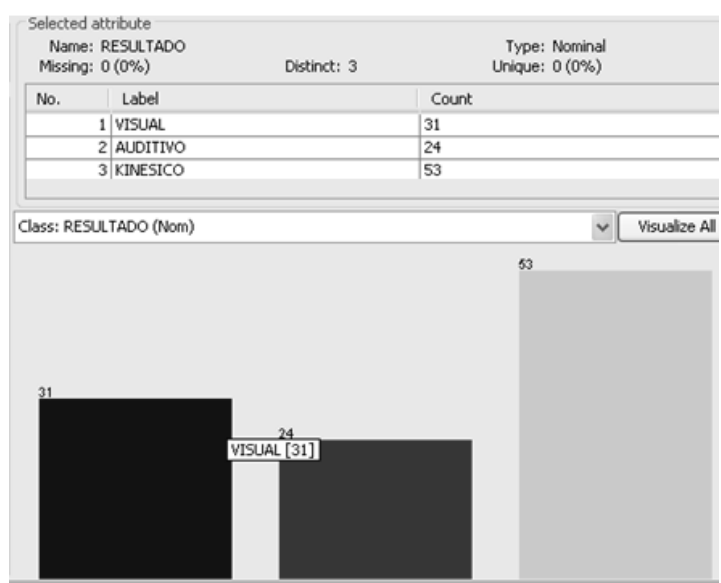

Fig. 13. Result of Kinesic Channel Predominance Source: Own Elaboration.

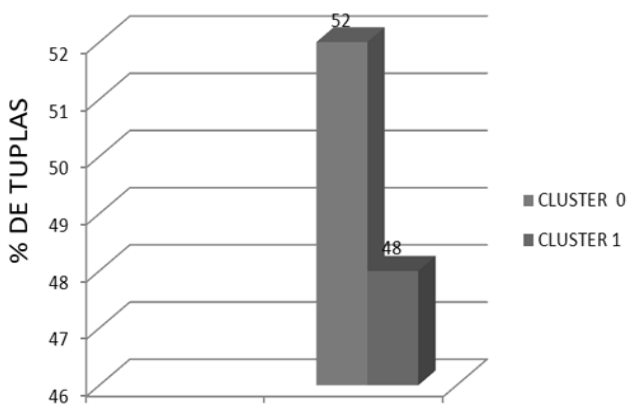

Fig. 14. Visualization of Clustering Results Source: Own Elaboration.

\section{B. Results}

As can be seen in Table III, the dominant style is kinesthetic with $49 \%$ (53 students), followed by visual $29 \%$ (31 students and auditory $22 \%$ (24 students), as well as the grouping of the different learning styles present in Fig. 15.

When it comes to evaluating an educational application, it is suggested to evaluate under two dimensions or criteria: computational and pedagogical.

TABLE. III. NumERICAL AND PERCENTAge Result of THE KDD Process

\begin{tabular}{|l|l|l|l|l|}
\hline \multirow{2}{*}{$\begin{array}{l}\text { V Cycle } \\
\text { Students }\end{array}$} & \multirow{2}{*}{ Applied Tests } & \multicolumn{3}{|l|}{ Learning Styles - NLP Model } \\
\cline { 3 - 5 } & & Visual & Auditive & Kinesic \\
\hline 108 & $108(100)$ & $31(29 \%)$ & $24(22 \%)$ & $53(49 \%)$ \\
\hline
\end{tabular}

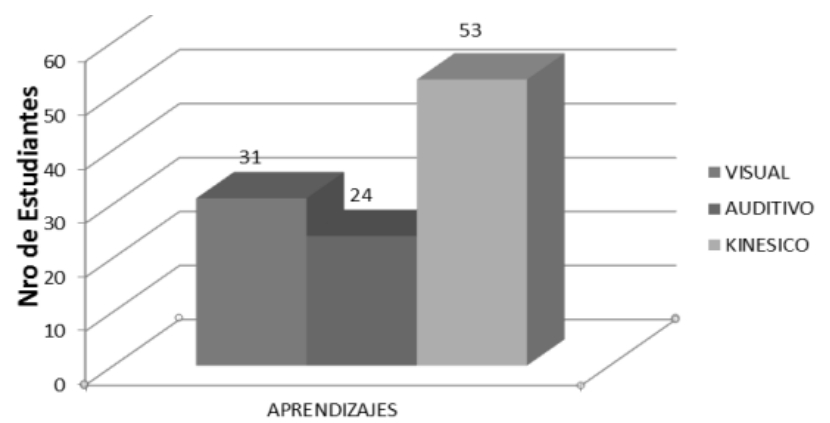

Fig. 15. Students Distributed by Learning Styles Source: Own Elaboration. 
Regarding the evaluation of computational design, undergraduate students of the professional career of Educational Sciences specialising in educational informatics (fifth year) of the National University of San Agustín of Arequipa-Peru took part, using the card shown in Table V. Once the answers were tabulated, the qualification of very good $(75.0 \%)$, good $(17.6 \%)$ and regular $(7.4 \%)$ was obtained, with the qualitative evaluation being very significant. What has been described is represented in Table IV and Fig. 16.

The evaluation under the pedagogical dimension was validated using the parameters of the PPP (classroom session) Table VI and Table I containing the items. The result of the application of these two instruments that formed the experimental control groups of the pre-test and post-test of the variable, strengthening of psychomotor communication skills, is illustrated in Table VII and Fig. 17.

When analyzing the results of the variable "psychomotor communication skills" - and in particular attention - it is observed that in the pre-test, the level is placed in: bad, with $51.1 \%$, followed by regular, with $48.9 \%$. While in the post-test the level rises to good, with $78.3 \%$ of students, followed by regular, with $21.7 \%$.

TABLE. IV. QuALITATIVE EVLUATION

\begin{tabular}{|l|l|l|}
\hline Criteria & Frequency & Percentage \\
\hline Very good & 81 & 75,0 \\
\hline Good & 19 & 17,6 \\
\hline Regular & 8 & 7,4 \\
\hline Bad & 0 & 0,0 \\
\hline & 108 & 100,0 \\
\hline
\end{tabular}

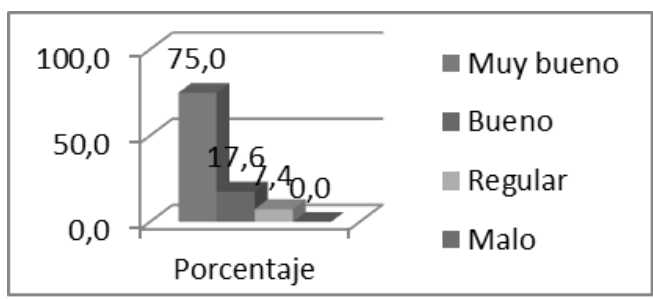

Fig. 16. Qualitative Evaluation Source Own Elaboration.

TABLE. V. Evaluation SHEEt, COMPUTER DESIGN

\begin{tabular}{|l|l|}
\hline Criteria & Weight (1-2) \\
\hline The application is easy to use. & \\
\hline It is possible to identify the links clearly & \\
\hline Sound quality and relevance & \\
\hline Quality and relevance of graphics and images & \\
\hline The interface design is appropriate & \\
\hline The interface is pleasant & \\
\hline It returns easily to the main menú & \\
\hline Access to submenus is easy & \\
\hline Promotes hardware or other equipment necessary for its use & \\
\hline Color scheme & \\
\hline
\end{tabular}

Source: Own elaboration

\section{TABLE. VI. PPP, PART 1. (ClASS SESSION)}

Development of psychomotor activities using new technologies reviewing different topological and spatial concepts

A. Name of the proposal for pedagogical practice

Review of topological and special concepts using new technologies

B. Activity name

We dance an andean song on a rug called "Tusuna_pad 1.0"

C. Purpose

Strengthen psychomotor communication skills and abilities accordingly contribute to the concentration in $\mathrm{V}$ cycle students

D. (Learning that students are expected to achieve)

- Perform Physical Activities to Develop Psychomotor Capabilities Through
the Application of the "Tusuna Pad 1.0" Application
- Motor and Perceptual Expression
- Development of Your Physical Qualities
- Stimulate Motor Capabilities and Playful Skills
- Rhythmic Discrimination And Reaction
- Psychomotor Control
- Organic Motor Expression

E. (Learning conditions)

- Organization and formation of work teams
- Normal physical attitude
- Respect the agreements and rules of the game
- Disposition of educational materials to use (Pcs, MPC Kit Tusuna -pad 1.0)
- Create a climate of trustUse the poster: What do we learn today?

F . (Sequence of actions (students and teacher))

\begin{tabular}{|c|c|c|c|}
\hline What will we do? & $\begin{array}{l}\text { What will we } \\
\text { need? }\end{array}$ & How we will do? & $\begin{array}{l}\text { When will } \\
\text { we do them? }\end{array}$ \\
\hline $\begin{array}{l}\text { Teacher: } \\
\text { - Apply a survey on } \\
\text { LS. } \\
\text { - Prepare and install } \\
\text { recreational } \\
\text { application. } \\
\text { Student: } \\
\text { - Have good discipline } \\
\text { and enthusiastic } \\
\text { attitude }\end{array}$ & $\begin{array}{l}\text { - Pcs from } \\
80586 \text { with } \\
\text { USB port. } \\
\text { - MPC kit } \\
\text { "tusuna-pad } \\
1.0 \\
\text { - PPP (learning } \\
\text { session }\end{array}$ & $\begin{array}{l}\text { - Read instructions on } \\
\text { the activity } \\
\text { "Concentration } \\
\text { Game" on the mat } \\
\text { with user interface } \\
\text { - Participating one by } \\
\text { one in the rug } \\
\text { Tusuna-pad 1.0. } \\
\text { - If you have several } \\
\text { kits groups of } 4 \text { in } 4\end{array}$ & \begin{tabular}{|l} 
- In the \\
classroom \\
- In physical \\
education \\
time.
\end{tabular} \\
\hline
\end{tabular}

Source: Own elaboration

TABLE. VII. PSYCHOMOTOR COMMUNICATION SKILLS

\begin{tabular}{|l|l|l|l|l|}
\hline & \multicolumn{2}{|l|}{ Pre-test } & Post-test \\
\cline { 2 - 5 } & $\mathrm{fi}$ & $\%$ & $\mathrm{fi}$ & $\%$ \\
\hline Bad & 47 & $51.1 \%$ & 0 & $0.0 \%$ \\
Regular & 45 & $48.9 \%$ & 20 & $21.7 \%$ \\
Good & 0 & $0.0 \%$ & 72 & $78.3 \%$ \\
\hline Total & 92 & $100 \%$ & 92 & $100 \%$ \\
\hline
\end{tabular}

That is to say, the students of the I.E. 40134 "Mandil Azul" of the district of Mariano Melgar belonging to the $\mathrm{V}$ Cycle of primary education, present a clear improvement when raising their level from bad to good of the pre to the post test, in the variable "psychomotor communicative skills, in particular the attention". 


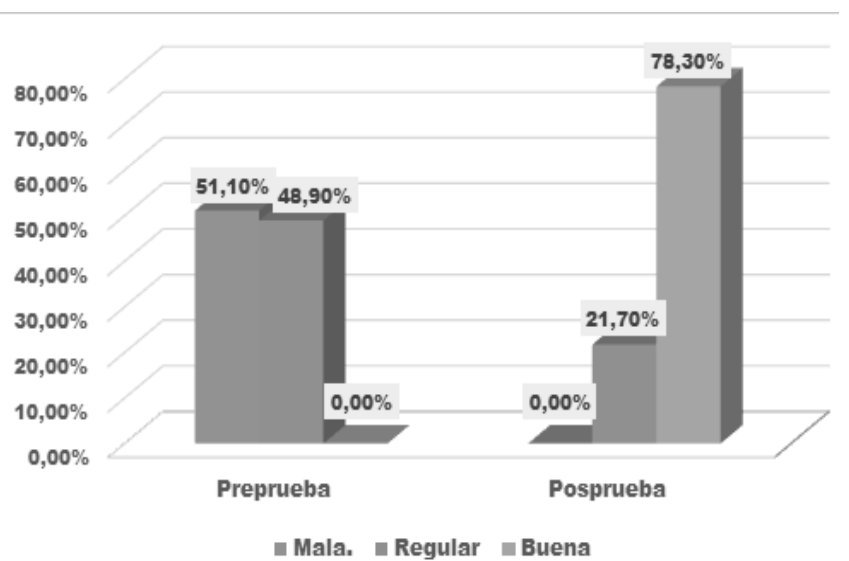

Fig. 17. Variable Representation of Psychomotor Communication Skills Source: Own Elaboration.

TABLE. VIII. LEVEL OF ATtENTION EVALUATION MATRIX

\begin{tabular}{|l|l|l|}
\hline $\begin{array}{l}\text { Level of } \\
\text { attention }\end{array}$ & Conceptualization & $\begin{array}{l}\text { Rhythm of the } \\
\text { game }\end{array}$ \\
\hline $\begin{array}{l}\text { Focused } \\
\text { attention }\end{array}$ & $\begin{array}{l}\text { Ability to respond separately to tactile, } \\
\text { audiovisual and auditory stimuli. Time is not } \\
\text { measured. }\end{array}$ & Relaxed \\
\hline $\begin{array}{l}\text { Sustained } \\
\text { attention }\end{array}$ & $\begin{array}{l}\text { It consists of maintaining a certain response } \\
\text { for a long period of time. It is the ability to } \\
\text { keep focused attention over time }\end{array}$ & Sequential \\
\hline $\begin{array}{l}\text { Alternate } \\
\text { attention }\end{array}$ & $\begin{array}{l}\text { Ability to change the focus of attention } \\
\text { between cue tasks require different comitive } \\
\text { responses. That is, it allows us to move from } \\
\text { one task to another. without sharing them } \\
\text { because they have nothing in common and } \\
\text { start one after finishing it without confusing } \\
\text { them. }\end{array}$ & Slow \\
\hline $\begin{array}{l}\text { Selective } \\
\text { attention }\end{array}$ & $\begin{array}{l}\text { Ability to remove the effect of distractions } \\
\text { that are unimportant to the task while } \\
\text { keeping the focus on the stimulus truly } \\
\text { relevant. In other words, to eliminate and } \\
\text { dispense with what is neither useful nor } \\
\text { necessary. }\end{array}$ & Hectic \\
\hline $\begin{array}{l}\text { Divided } \\
\text { attention }\end{array}$ & $\begin{array}{l}\text { Ability to attend to different stimuli at the } \\
\text { same time without making mistakes in } \\
\text { execution, temple driving and being able to } \\
\text { speak with the driver. }\end{array}$ & Quick \\
\hline
\end{tabular}

\section{Learning style test (NLP model) - Part 1}

Instructions: Choose an option with which you identify most of each of the questions and mark it with an X. There are no right or wrong answers. The important thing is that you be honest with your answers.

TABLE. IX. Percentage Distribution in Relation to LeVel of CARE

\begin{tabular}{|l|l|l|}
\hline Range of percentage & Level of attention & Rythm \\
\hline $0 \%-5 \%$ & Focalized & Relaxed \\
\hline $6 \%-10 \%$ & Sustained & Sequenced \\
\hline $11 \%-25 \%$ & Alternate & Paused \\
\hline $26 \%-50 \%$ & Selective & Frenetic \\
\hline $51 \%-100 \%$ & Divided & Rapid \\
\hline
\end{tabular}

TABLE. X. REAGENT SHEET FROM THE NLP TEST QUESTIONNAIRE SOURCE MODIFIED IN CONTENT AND FORM, VERACRUZ [42]

\begin{tabular}{|c|c|c|c|}
\hline \multirow{3}{*}{1} & \multirow{3}{*}{$\begin{array}{l}\text { Which of the following } \\
\text { activities do you enjoy most? }\end{array}$} & $\mathrm{a}$ & Listen to music \\
\hline & & $\mathrm{b}$ & Watch movies \\
\hline & & c & Dance with good music \\
\hline \multirow{3}{*}{2} & \multirow{3}{*}{$\begin{array}{l}\text { What television show do you } \\
\text { prefer? }\end{array}$} & $\mathrm{a}$ & World News \\
\hline & & $\mathrm{b}$ & Reports of discoveries, places \\
\hline & & c & Comic and entertainment \\
\hline \multirow{3}{*}{3} & \multirow{3}{*}{$\begin{array}{l}\text { When you talk with another } \\
\text { person, you: }\end{array}$} & $\mathrm{a}$ & You watch her \\
\hline & & $\mathrm{b}$ & You listen carefully \\
\hline & & $\mathrm{c}$ & You tend to touch her \\
\hline \multirow{3}{*}{4} & \multirow{3}{*}{$\begin{array}{l}\text { If you could purchase one of } \\
\text { the following items, which } \\
\text { one would you choose? }\end{array}$} & $\mathrm{a}$ & TV \\
\hline & & $\mathrm{b}$ & Radio \\
\hline & & c & Bike \\
\hline \multirow{3}{*}{5} & \multirow{3}{*}{$\begin{array}{l}\text { What do you prefer to do on a } \\
\text { Saturday afternoon? }\end{array}$} & $\mathrm{a}$ & Go to the movies \\
\hline & & $\mathrm{b}$ & Go to a concert \\
\hline & & $\mathrm{c}$ & Stay at home \\
\hline \multirow{3}{*}{6} & \multirow{3}{*}{$\begin{array}{l}\text { What type of exams are best } \\
\text { provided for you? }\end{array}$} & $\mathrm{a}$ & Written exam \\
\hline & & $\mathrm{b}$ & Oral exam \\
\hline & & $\mathrm{c}$ & Multiple choice exam \\
\hline \multirow{3}{*}{7} & \multirow{3}{*}{$\begin{array}{l}\text { How do you orientate yourself } \\
\text { more easily? }\end{array}$} & $\mathrm{a}$ & By using a map \\
\hline & & $\mathrm{b}$ & Asking for directions \\
\hline & & $\mathrm{c}$ & Through intuition \\
\hline \multirow{3}{*}{8} & \multirow{3}{*}{$\begin{array}{l}\text { What do you prefer to spend } \\
\text { your time in a resting place? }\end{array}$} & $\mathrm{a}$ & Walking \\
\hline & & $\mathrm{b}$ & Thinking \\
\hline & & c & Rest \\
\hline \multirow{3}{*}{9} & & $\mathrm{a}$ & You look good \\
\hline & What flatters you the most? & $\mathrm{b}$ & You have an interesting talk \\
\hline & & $\mathrm{c}$ & You have a very nice treatment \\
\hline & & $\mathrm{a}$ & A beautiful ocean view \\
\hline 10 & Which of these environments & $\mathrm{b}$ & Hear the waves of the sea \\
\hline & & c & A pleasant climate sits \\
\hline & & $\mathrm{a}$ & Writing several times \\
\hline 11 & How do you facilitate learning & $\mathrm{b}$ & Repeating out loud \\
\hline & & $\mathrm{c}$ & Matching it with something fun \\
\hline & & $\mathrm{a}$ & Art exhibition \\
\hline 12 & What event would you rather & $\mathrm{b}$ & Confenrence \\
\hline & & $\mathrm{c}$ & A dance social gathering \\
\hline & & $\mathrm{a}$ & By its appearance \\
\hline 13 & How do you form an opinion & $\mathrm{b}$ & For the sincerity in his voice \\
\hline & & c & By the way you shake hands \\
\hline & & $\mathrm{a}$ & Athletic \\
\hline 14 & How do you consider & $\mathrm{b}$ & Intellectual \\
\hline & & c & Sociable \\
\hline & & $\mathrm{a}$ & De acción \\
\hline 15 & ¿Que tipo de peliculas te & $\mathrm{b}$ & Clásicas \\
\hline & & $\mathrm{c}$ & De amor \\
\hline & & $\mathrm{a}$ & E-mail \\
\hline 16 & How do you prefer to keep in & $\mathrm{b}$ & Phone \\
\hline & & $\mathrm{c}$ & Having coffee together \\
\hline & & $\mathrm{a}$ & It is important that my bike is clean \\
\hline 17 & $\begin{array}{l}\text { Which of the following } \\
\text { phrases identify most with }\end{array}$ & $\mathrm{b}$ & $\begin{array}{l}\text { I perceive even the slightest noise my } \\
\text { bike makes }\end{array}$ \\
\hline & & c & $\begin{array}{l}\text { I like my bike to feel good when } \\
\text { driving it }\end{array}$ \\
\hline & How do you prefer to spend & $\mathrm{a}$ & Watching something together \\
\hline 18 & time with your best friend or & $\mathrm{b}$ & Talking \\
\hline & friend? & c & Playing \\
\hline & & $\mathrm{a}$ & You are looking for it \\
\hline 19 & If you can't find the keys in a & $\mathrm{b}$ & You shake the bag to hear the noise \\
\hline & & c & You look for the touch \\
\hline & & $\mathrm{a}$ & Images \\
\hline 20 & When you try to remember & $\mathrm{b}$ & Sounds \\
\hline & & $\mathrm{c}$ & Emotions \\
\hline
\end{tabular}




\section{CONClusions}

The results show that the application of the clustering analysis technique to the students of the EBR $V$ cycle of IE 40134 made it possible to determine the predominance of the kinesthetic learning style with $49 \%$, followed by the visual $29 \%$ and auditory $22 \%$, of the whole population under study.

With the results obtained from educational DMs, it was possible to implement an application and hardware device baptized with the name of "Tusuna-pad 1.0", a multifunctional learning kit as a contribution to the new design of computerized pedagogical materials, with emphasis on the practice of the kinesthetic and haptic channel for EBR learners, making the teacher's work easier as facilitator and guide, supported by technological devices.

It was proven that the use of the surroundings allows the student to contribute to the improvement of attention as a result of the strengthening of psychomotor communication skills. Considering the analysis of the results of the variable "psychomotor communication skills", in particular attention, it is observed that in the pre-test the level is situated in bad at $51.1 \%$, followed by regular at $48.9 \%$. While in the post-test the level rises to good with $78.3 \%$ of students, followed by regular with $21.7 \%$. That is to say that the students of the IE 40134 of the $\mathrm{V}$ primary cycle, present improvement when raising their level from bad to good, from the pre to post test, in the variable mentioned.

\section{FUTURE WORK}

To the scientific community we present the following scheme Fig. 18, whose purpose is to design and implement a pedagogical hyper-intelligent / hyper-learning model mediated by intelligent virtual pedagogical agents (APVI) with topics based on the disciplines of Neuroscience, Neuropsychology and NLP, which allows to dose pedagogical strategies, organize contents and intelligent curricula with conceptual, attitudinal and procedural intelligent learning, as the learning by reinforcement was computationally modeled, and knowledge of the behavioral school of Skinner and Watson, which now forms part of the line of artificial intelligence research called Qlearning.

An integrated model with MAS-ALEGRO (Multi-Agent System) uses the approach of the pedagogical agents, with the capacity to provide individualized and collaborative teaching at the same time. MAS-PLANG (New Generation Platform), designed to provide adaptive support. The HABITATPRO, tool designed for content customization. FSLSM (Felder and Silverman Learning Style Model), allows students to categorize according to their ability to process, perceive, receive, organize and understand information. Agent SONIA, works cooperatively with agents, controls navigation. JAFIMA, allows to develop cognitive agents with capacities of perception, communication, mobility, reaction and behavior directed by objectives. There are enough tools to achieve the proposal. If the international scientific community takes the proposal into consideration, an intelligent technological application can be developed to support education. The objective is to raise the level of education in underdeveloped countries. In fact, it is multidisciplinary work.

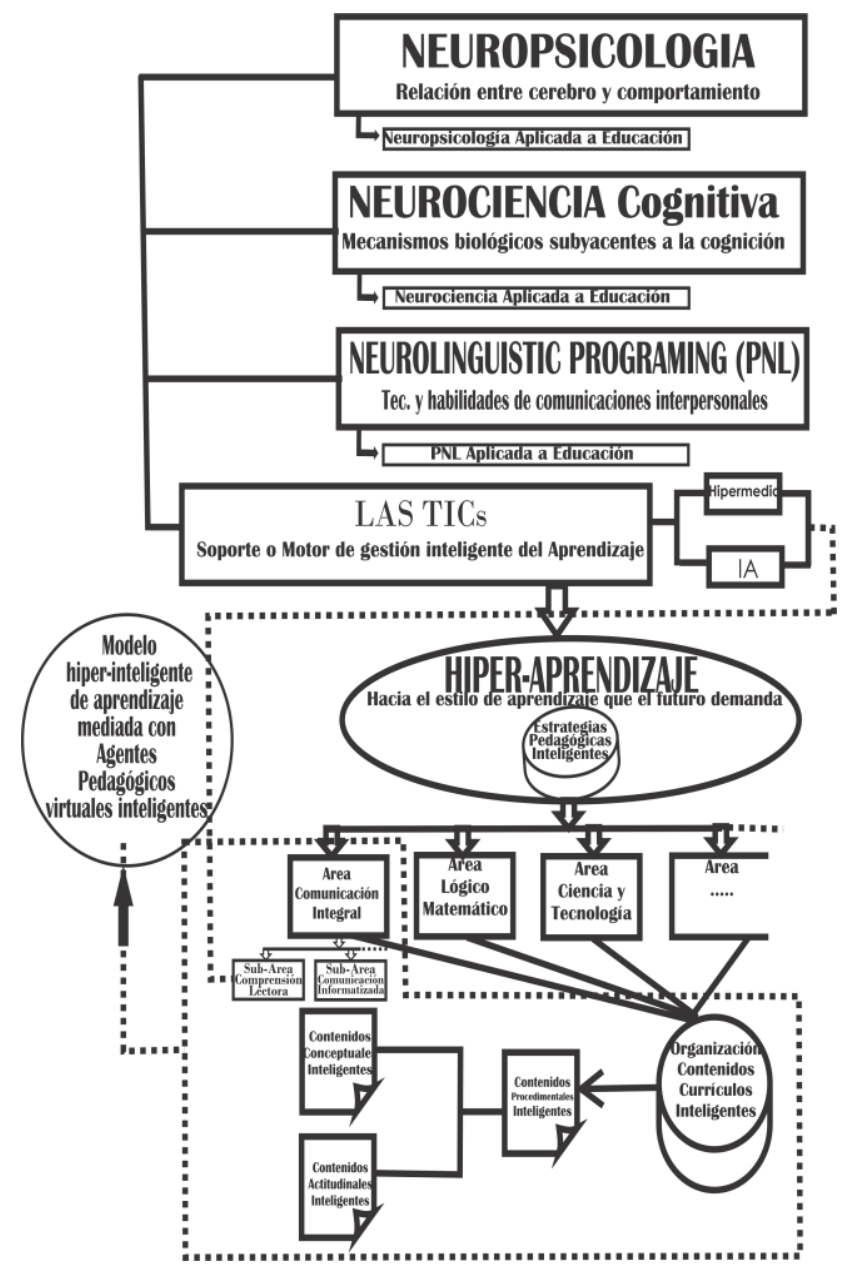

Fig. 18. Architecture of a Multidisciplinary Hyper-Intelligent Learning Model Source Own Elaboration.

REFERENCES

[1] Gramigna, A., \& González, J. C. (2009). Videojugando se aprende: renovar la teoría del conocimiento y la Educación.Comunicar,7(33), 157-164. https://doi.org/10.3916/c33-2009-03-007.

[2] Sánchez, J., \& Saenz, M. (2006). 3D sound interactive environments for blind children problem solving skills. Behaviour \& Information Technology, 25(4), 367-378.

[3] Huizinga, Johan (2012). Homo Ludens. Translation: Eugenio Imaz Echeverría Alianza Editorial. Madrid-España.

[4] Margulis, Lucio y Martínez, Javier (2010). To play is to learn by doing. http://www.catenaria.cl/img/pdf/.

Neruda, Pablo. (1974). I confess that I have lived Valparaíso-Chile.

[5] Kotsiantis, S. Patriarcheas, K. and Xenos, M. (2010). A Combinational Incremental Ensemble of Classifiers as a Technique for Predicting Students Perfomance in distance Educatión, Knowledge Base Systema, Vol. 23, no 6, pp. 529-535.

[6] Más, J. Alcover, R. Dapena, A. Valdenuten, A. Satorre R. Llopis, F. Rojo, T. Mayo, R. Bermejo, M. Gutierrez, J. Garcia, J. Tovar, E. y, Menasalvas, E. (2009). Academic Performance of Computer Studies in Some Spanish Centers. XV University Teaching Conference on Computer Science, Barcelona, Conference Report.

[7] Gómez del Valle, Manuel (2003). Identification of predominant learning styles in teachers of the Faculty of Education Sciences of the University of Cádiz. ISSN-e 1575-0965, Vol. 6, Nº. 2. Spain: Dialnet.

[8] García, José Sanizo, José y Jiménez, Mercedes. IV world congress of learning styles. Graduate College Learning Styles Magazine, Vol. 10, Núm. 10. Campus Montecillo. México. 
[9] Choquehuayta, Simón. (2011). New trends in learning with digital technology. TISE 2011, International Congress of Educational Informatics. University of Chile. Faculty of Computer Science, Physical Sciences and Mathematics. Santiago, Chile.

[10] Cárdenas, Rocío y Herrera, José (2014). Proposal of a methodology for the design of an educational game interface for children from 4 to 5 years with mobile devices. Science and technology magazine ISSN 2304-8891: 2014 Tacna Perú.

[11] Mérida, David. (2002). SHAAD: Adaptive, Adaptable and Dynamic Hypermedia System for content delivery. Research Project, Information Technology PhD Program - Department of Electronics, Computer Science and Automation. Girona, 2002.

[12] Goebel, Jenny (2012). Can 'DDR' and 'ITG' Can Boost Intelligence? The Ultimate Brain Gym. http://www.smart-kit.com/s142/how-ddr-anditg-can-boost-intelligence-the-ultimate-brain-gym/.

[13] Gómez-Martín M. Gómez-Martín, P. and González-Calero, Pedro A. (2014). Learning based on games Computer Systems and Programming Department Complutense University of Madrid. Year 2 - Vol. 2 Journal of Communication and New Technologies ISSN: $1697-8293$. Spain.

[14] Olague Sánchez, Juan Ramón; Torres Ovalle, Sócrates; Morales Rodríguez, Felipe; Valdez Menchaca, Alicia Guadalupe; Silva Avila, Alicia Elena. Sistemas de gestión de contenidos de aprendizaje y técnicas de minería de datos para la enseñanza de ciencias computacionales. Un caso de estudio en el norte de Coahuila Revista Mexicana de Investigación Educativa, vol. 15, núm. 45, abril-julio, 2010, pp. 391-421 Consejo Mexicano de Investigación Educativa, A.C. Distrito Federal, México.

[15] Sánchez, J. y Ovalle, S. (2010). Application of data mining techniques and learning content management systems for the development of a computer learning system for computer programming. X National Congress of Educational Research. Mexico.

[16] Gutiérrez Fernández M. Romero Cuadrado, M. \& Solórzano García M. (2011). Experiential learning as a teaching methodology: application of the Macbet method. Argos Magazine, 28(54),127-158.

[17] Costaguta, R y Gola, M. (2006). Identification of dominant learning styles in computer students. In XV Argentine Congress of Computer Science.

[18] Durán, E. y Costaguta (2007). Data mining to discover learning styles. Revista Iberoamericana de Edición, ISSN 1681-5653. http://www. Rieoei.org/deloselectores/1674Duran.pdf.[36] Felder, R Soloman, V. (1984). Index of Learning Styles.http://.ncsu.edu/felder-public.

[19] Richard M. Felder and Barbara A. Soloman (1993). Index of Learning Styles Questionnaire. North Carolina State University.

[20] Felder, R Silverman, L. (1988). Learning and Teaching Styles in Engineering Education Application. Engr. Education, Vol. 78(7), pp.674-681.

[21] Chumirayco, M. (2009). Neurolinguistic programming in the strategic learning of the students of the I Cycle in the professional schools of Initial and Primary Education of the University César Vallejo. Universidad Mayor San Marcos. Lima-Perú. Tesis de Maestría.

[22] Cecily Heiner, Ryan Baker y Kalina Yacef. (2006). Proceedings of the Workshop on Educational Data Mining at the 8th International Conference on Intelligent Tutoring Systems (ITS. Jhongli, Taiwan.

[23] Ballesteros, A. Sánchez, D. and García R. (2013). Data mining: A tool for researching learning patterns in an educational context. Center for Research in Applied Science and Advanced Technology, Legaria Unit of the National Polytechnic Institute. Calzada Legaria, No. 694, Col. Irrigación. Del. Miguel Hidalgo, C. P. 11500, México D. F. México.
[24] Oconnor Joseph, Seymour John. (2007). Introduction to neurolinguistic programming. Ediciones Urano S.A. Printed in Barcelona-Spain.

[25] Rassmus Kirsten (2008). User-Centered Design of Non-Visual AudioHaptics. Certec, Rehabilitation Engineering Research. Department of Design Sciences. Faculty of Engineering Lund University. Tesis doctoral.

[26] C. Colwell, H. Petrie, A. Hardwick and S. Furner (1998). Haptic Virtual Reality for Blind Computer Users, ASSETS 98, pp 92-99.

[27] Cortés, F. y Meñacca, I. (2016). Play: a strategy for the teachinglearning in virtual environments of the non-commissioned officers of the infantry training school of Marina de Coveñas Sucre, Colombia. Scientific and technological research article. Palabra Nro. 16, August.

[28] Campo, M. y Gálvez, P. (2006). The game as a pedagogical strategy: A situation of educational interaction. Grade work. Santiago-Chile: Universidad de Chile.

[29] Torres, C. y Torres M. (2007). Play as a learning strategy in the classroom. Venezuela: Universidad de los Andes.

[30] Chacón, P. (2008). The didactic game as a teaching and learning strategy How to create it in the classroom? Revista Nueva Aula Abierta Nro. 16, año 5. Caracas Universidad Pedagógica Experimental Libertad.

[31] Padilla, N.; Collazos, C.; Gutiérrez, F.; Medina, N. (2012). Educational Video Games: Theories and Proposals for Group Learning. Ciencia e Ingeniería Neogranadina 22 (1). ISSN 0124-8170.

[32] Claire Selltiz, Lawrence S. Wrightsman, Stuart W. Cook. (2014). Research methods in social relations. New York: Holt, Rinehart and Winston.

[33] Giorgi, (1978). Participatory action research: a methodological option. Uruguay.

[34] Ruiz, F., Polo, M., Piattini, M. (2002). Use of Research-Action in the Definition of an Environment for the Management of the Software Maintenance Process 1st Workshop in: Research Methods and Philosophical Fundamentals in Software Engineering and Information Systems.

[35] Matas Toni y Dalmau. (2012). Multimedia Products: Design and Conceptual Analysis. Editor of Barcelona Multimedia. directa@ bcnmultimedia.com. España.

[36] Bandler, Richard and John Grinder (1975). The Structure of Magic I: A Book About Language and Therapy. Palo Alto, CA: Science \& Behavior Books. ISBN 0831400447.

[37] Frawley, W. Piatetsky-Shapiro, G. and Matheus, C. (1992). Knowledge discovery in databases: An Overview. AI magazine, 13(3), 57.

[38] Han, J. Kamber, M. (2001). Data Mining: Concepts and Techniques. Morgan-Kaufmann Academic Press, San Francisco EE.UU.

[39] Núñez, F. Hernandez, R. Tomás, V. y Felipe, A. (2013). Identification of learning styles in university students of computation of the Huasteca Hidalguense by means of Data Mining Techniques. University of the State of Hidalgo. Escuela Superior Huejutla. https://www.uaeh.edu. $\mathrm{mx} /$ investigacion/productos/5566/estilos_de_aprendizaje.pdf.

[40] Chandhuri, Siva Garg, Naveen Ravi, R. (1997). The p-neighbor k-center problem. Carnegie Mellon University. Research Showcase@CMU.

[41] Secretary of Education of the State of Veracruz. (2014). http://www. orientacion andujar.es/wp-content/uploads/2014/09/test-estilo-deapren dizajes.pdf.

[42] Choquehuayta, S., Alfaro, L. y Herrera, J. (2017). Learning environment, based on the neurolinguistic programming approach (NLP): Kinese-properceptive learning system. Revista Referencia pedagógica. Año 2017. Número 1, ISSN 2308-3042. http://rrp.cujae. edu.cu/index.php/rrp/article/view/117. 